\title{
RESENHA
}

\section{Por Trás dos Canaviais, os "Nós" da Cana a relação capital $x$ trabalho e o movimento sindical dos trabalhadores da agroindústria canavieira paulista}

\section{ANTONIO THOMAZ JÚNIOR}

Fapesp/Anablume, 2002

A globalização financeira forçou a reorganização industrial, dando num rearranjo por inteiro da relação capital-trabalho no mundo da indústria. O livro de Antonio Thomaz Jr. analisa esta reestruturação no âmbito da indústria sucroalcooleira de São Paulo.

A estratégia da modernização do campo dos anos 70 bancada pelo governo militar através da estratégia do I PND leva à proliferação da agroindústria no Brasil, com forte impacto sobre as agroindústrias tradicionais como a agroindústria açucareira. A crise do petróleo desencadeada a partir de 1973, pegando a modernização agroindustrial do setor açucareiro em pleno voo, traz consigo o Programa do Próalcool, encaminhando a agroindústria a converter-se num complexo açucar-álcool combustível, que é a origem da grande transformação que a partir de então vai experimentar esse setor, particularmente em São Paulo.

A modernização tecnológica se orienta então neste sentido, acabando por converte a agroindústria num complexo agroindustrial, do qual faz parte toda uma atividade de pesquisa em engenharia genética realizada no âmbito da própria indústria. A diversificação produtiva no interior da usina e a troca permanente da semente da cana por plantas seguidamente recriada nos laboratórios da biotecnologia alteram por completo a planta da indústria e o conjunto inteiro da relação indústria-agricultura no plano de cada indústria sucroalcooleira do Estado de São Paulo.

A nova forma de organização do capital impacta o mundo do trabalho, engen- 
drando uma ampla alteração no quadro da relação capital-trabalho no âmbito global da indústria. Reestruturam-se as relações do trabalho dentro da usina-destilaria e dentro da lavoura da cana, reorientando-se o universo do complexo agroindustrial sucroalcooleiro como um todo.

"Por Trás dos Canaviais" analisa o movimento destas transformações. Faz o mapeamento da reestuturação tecnológica, mostrando a implementação da pesquisa biotecnológica, a renovação da planta industrial adaptando-a à nova função e as novas formas de organização do plantio. Mostra o quadro das novas regras de regulação, detalhando o processo da reeestruturação do trabalho dentro da fábrica e dos canaviais, as implicações da invação tecnológica na divisão territorial do trabalho dentro do complexo e o problema então criado de desemprego. E, por fim, oferece ao leitor a oportunidade do acompanhamento das grandes mudanças que tudo isto ocasiona no plano da reestruturação produtiva.

Da análise do capital, Thomaz Júnior passa para a análise do movimento sindical. A luta dos trabalhadores da usina e da lavoura da cana é apresentada em toda suas nuanças. As novas formas de luta, as novas reinvindicações, o problema da unidade sindical em vista da própria forma como o sindicalismo organiza em separado a ação dos trabalhadores do campo e da cidade, as soluções e alternativas aí encontradas, são os temas que o autor investiga. E, então, os termos e as novas formas de contradições sociais introduzidas no mundo da agroindústrias pela sequência das suas reestruturações.

Toda uma pesquisa de campo embasa esta análise tão ampla de reestruturação e conflitos recentemente ocorridas em um dos setores mais importantes da economia de São Paulo e do país. Neste caso, dado o papel crescente que a agroindústria sucroalcooleira passa a ter após os anos 70 na política energética do país. Também aqui há um minucioso detalhamento, com o autor apresentando ao leitor seus procedimentos de método e opções de referência teórico-conceitual dentro do universo da geografia renovada.

O trabalho é enriquecido de uma profusão de mapas, dando todos os detalhes da geografia do complexo, da nova planta às relações de trabalho na indústria e na agricultura da cana.

(Ruy Moreira) 